\title{
20: 29774317-29715924
}

National Cancer Institute

\section{Source}

National Cancer Institute. 20:29774317-29715924. NCI Thesaurus. Code C41762.

Physical location of BCL2L1_Gene 